\title{
A Hardware Testbed of Grid-Connected Wind-Solar Power System
}

\author{
Aryuanto SOETEDJO, Member, IEEE, Abraham LOMI, Senior Member, IEEE, Bayu Jaya PUSPITA
}

\begin{abstract}
This paper presents the development of hardware testbed for implementing grid connected wind-solar power system. A solar simulator using halogen lamp is employed to simulate the sun irradiation. The wind power simulator is developed by coupling the DC motor and the DC generator. A grid tie inverter is employed to connect the power from the solar and wind power system with the grid system. The experimental results show that the developed testbed could be used for testing the hybrid power system in the real hardware.
\end{abstract}

Index Terms - Grid connected, wind power system, solar power system, grid tie inverter, hardware testbed.

\section{INTRODUCTION}

$\mathbf{R}$ ecently, the use of wind and solar as the power generation is increasing rapidly, either operated in isolated mode or connected to the grid. Since the availability of wind and solar power fluctuate according to the environments (sun and wind), the electrical connection to the grid should be designed properly [1]-[12].

In the grid-connected system, grid synchronization is a complicated problem, due to the requirement of phase and voltage synchronization of AC grid system. To simplify the system, the DC load was proposed in [1]. In the system, the diode switching unit was employed to supply the DC load from various power sources, i.e the grid and the battery (from solar power system). The battery was charged by the charger unit equipped with a MPPT (Maximum Power Point Tracking) to get the maximum energy from the solar panel.

In [2], the hybrid solar - wind power systems were designed to operate either in the connected with the grid and stand-alone mode. A grid inverter was developed for operating in both modes. In [3], [4], [5], solar and wind power systems were connected via the DC bus, then injected to the AC grid using inverter. In [6], [7], the wind power, solar power and the grid were connected using AC bus.

Due to the complicated and high costs for implementing the hybrid power systems, most works described previously implemented and tested the algorithms using the simulation systems [3] - [6], [8] - [12]. In [2], the hybrid wind-solar power system was implemented on the laboratory scale. The system consisted of 600 Watt wind generator and 400 Watt solar panel.

Manuscript received October 11, 2017; revised November 14, 2017; accepted November 29, 2017.

Aryuanto Soetedjo and Abraham Lomi are with the Department of Electrical Engineering, National Institute of Technology, Malang, Indonesia (email: aryuanto@lecturer.itn.ac.id; abraham@lecturer.itn.ac.id).

Bayu Jaya Puspita is with the Control Laboratory, National Institute of Technology, Malang, Indonesia.
In this paper, we develop a testbed for implementing the hybrid wind-solar power system. The wind power system is simulated using a generator coupled with a motor. While the solar power system is simulated using the halogen lamp and solar panel. The grid-tie inverter is employed to connect the renewable energy resources to the grid. The objective of research is to test the functionality and performance of the hardware testbed for implementing the grid-connected WindPV system.

\section{SYSTEM ARCHITECTURE}

The architecture of hybrid power system is shown in Fig. 1. There are two renewable energy resources, i.e. PV power generator and wind power generator. The PV power generator system consists of a solar power simulator, a charge controller, a battery, and a grid-tie inverter. The wind power generator system consists of a wind power simulator, a charge controller, a battery, and a grid-tied inverter. As shown in the figure, all power resources (PV, wind power, and grid) and the load are connected via the AC line. The components of each sub-system are described in the following.

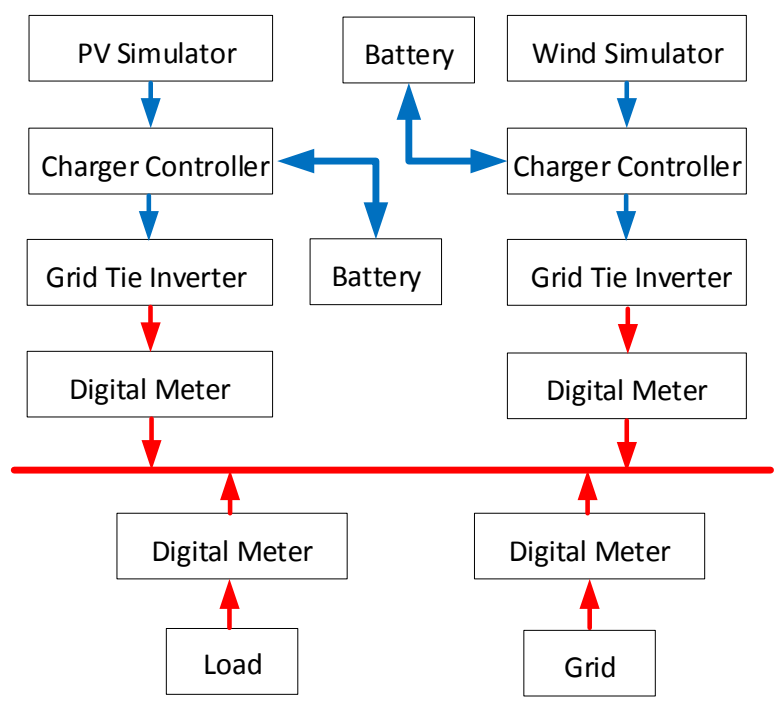

Fig. 1. Architecture of hybrid power system testbed

\section{A. Solar Power Simulator}

The solar power simulator consists of two PV units $(2 \times 50$ Watt peak) and a halogen lamp of 1000 Watt. The specification of $\mathrm{PV}$ is as follows:

$$
\begin{aligned}
& -\mathrm{P}_{\max }=50 \text { Watt } \\
& -\mathrm{V}_{\mathrm{pm}}=17.5 \text { Volt }
\end{aligned}
$$


- $\mathrm{I}_{\mathrm{pm}}=2.86$ Ampere

$-\mathrm{V}_{\text {oc }}=21.5$ Volt

- $\mathrm{I}_{\mathrm{sc}}=3.25$ Ampere

Two PV units are connected in series.

To simulate the sun irradiation, a halogen lamp is employed. The halogen lamp is effective to simulate the sun irradiation as proposed in [13]. The hardware of PV and halogen lamp is illustrated in Fig. 2. In the experiments, the distance between halogen lamp and solar panel is varied to change the irradiation, yields in the changing of power generated by the solar panel.

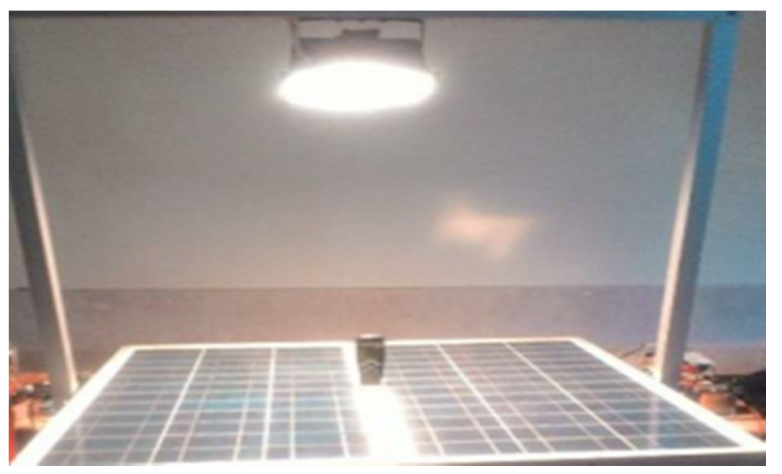

Fig. 2. Picture of solar panel and halogen lamp.

\section{B. Wind Power Simulator}

The wind power simulator is depicted in Fig. 3. It consists of a DC generator whose axis is coupled with a DC motor. The specification of DC motor and generator is as follows:

- Non gearbox

- Permanent magnet

- Speed : $1000 \mathrm{rpm}$

- Voltage : DC 12V-18V

- Current : 15A

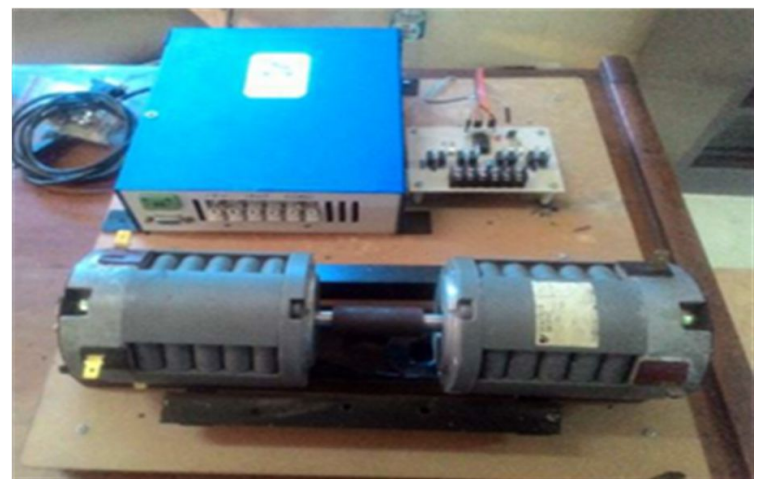

Fig. 3. Picture of DC generator and DC motor.

Using the arrangement, the power output of generator could be varied by changing the speed of motor coupled with it.

\section{Charge Controller}

Charge controller is employed to control the charging process to the battery. The charge controller used here is TracerBN Series MPPT Solar Charge Controller [14]. The MPPT (Maximum Power Point Tracking) technique employed in the controller ensures that the solar panel always operates in the maximum power, thus the power extracted from the PV is always maximum.

The MPPT technique is illustrated in Fig. 4 [14]. In the figure, the shaded green area is the operating area of the conventional PWM charge control. While the MPPT technique tracks the system to move the operating point to MPP point. In this point, the power is the maximum one (see power curve in Fig. 4).

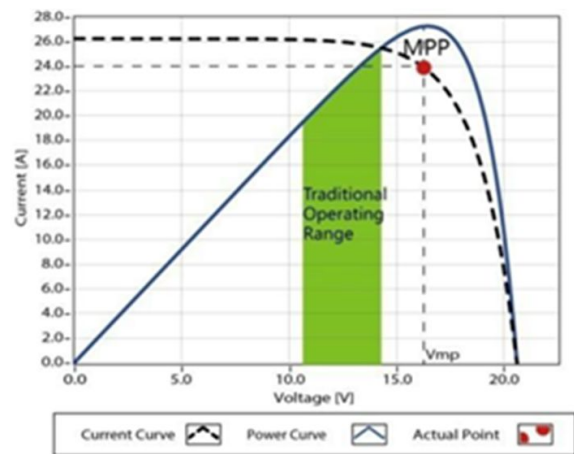

Fig. 4. MPPT curve [14].

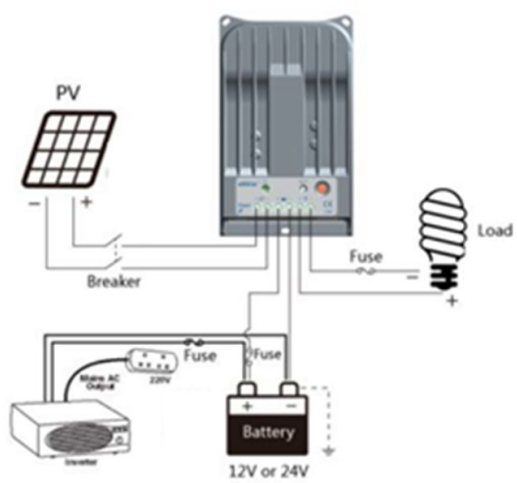

Figure 5. The connection of MPPT charge controller [14].

The connection between MPPT charge controller, solar panel (PV), battery, DC load and inverter is depicted in Fig. 5. As shown in the figure, the inverter is connected in parallel with the battery. The specification of MPPT charge controller is as follows:

- Nominal system voltage : $12 / 24 \mathrm{~V}$ auto work

- Rated battery current : 30A

- Rated load current : 20A

- Max input power : 390W (12V) 760W(24V)

\section{Grid Tie Inverter}

The grid tie inverter is a DC to AC inverter in which the AC output is synchronized with the existing grid. The converter detects the phase and frequency of the grid then synchronizes the output with the grid. The specification of grid tie inverter used in the experiment is as follows:

- Power : $600 \mathrm{~W}$

- Voltage input : 22 - 60 VDC

- Voltage output : 190 - 260 VAC

- Frequency range : $45 \mathrm{~Hz}-63 \mathrm{~Hz}$ 


\section{E. Digital Meter}

The digital meter (power meter) is used to measure the voltage, current and power flowing in the system as shown in Fig. 1. To provide easy measurement and capability for advanced monitoring, the digital meter equipped with communication line (communication protocol) is employed). The specification of digital meter is as follows [15]:

- Voltage : 220 VAC (Single phase ph-N)

- Measurement : Voltage, Current, Power, Energy

- Rated (Max) current : 5 (63) A

- Frequency : $50 \mathrm{~Hz} / 60 \mathrm{~Hz}$

- Power consumption : $2 \mathrm{~W}$

- Communication : RS485 port, MODBUS-RTU

\section{EXPERIMENTAL RESULTS}

\section{A. Solar Power Simulator Measurement}

1) Measurement of PV output due to the sun lighting

The measurement of PV output due to the sun lighting is conducted to measure the PV power output when illuminated by the sun. In the experiment, the PV is placed in outdoor from 09:00 to 15:00 and the measurement is conducted in 30 minutes interval. Two PV units are connected in series and the output is connected to the MPPT charge controller. The battery is connected to the output of the MPPT charge controller. The sun irradiation is measured using the Solar Power Meter [16] that has the resolution of $0.1 \mathrm{~W} / \mathrm{m}^{2}$ and the accuracy of $+/-10 \mathrm{~W} / \mathrm{m}^{2}$.

TABLE I. MEASUREMENT RESUlt USING SuN

\begin{tabular}{ccccc}
\hline \hline Time & $\begin{array}{c}\text { Irradiation } \\
\text { (Watt/m } \mathbf{m}^{\mathbf{}} \text { ) }\end{array}$ & $\begin{array}{c}\text { Voltage } \\
\text { output } \\
\text { (Volt) }\end{array}$ & $\begin{array}{c}\text { Current } \\
\text { output } \\
\text { (Ampere) }\end{array}$ & $\begin{array}{c}\text { Power } \\
\text { output } \\
\text { (Watt) }\end{array}$ \\
\hline \hline 09:00 & 465 & 30 & 1.8 & 53.9 \\
$09: 30$ & 456 & 30.3 & 1.6 & 49.1 \\
$10: 00$ & 570 & 27.6 & 2.2 & 61.2 \\
$10: 30$ & 800 & 31.7 & 2.7 & 84 \\
$11: 00$ & 660 & 32.1 & 2.1 & 67.6 \\
$11: 30$ & 820 & 36.7 & 2.4 & 88.1 \\
$12: 00$ & 760 & 28 & 2.8 & 77.0 \\
$12: 30$ & 730 & 26.7 & 2.8 & 74.3 \\
$13: 00$ & 760 & 28 & 2.8 & 77.0 \\
$13: 30$ & 730 & 26.7 & 2.8 & 74.3 \\
$14: 00$ & 179 & 26.4 & 0.7 & 18.5 \\
$14: 30$ & 92 & 26.2 & 0.4 & 9.7 \\
$15: 00$ & 60 & 26.1 & 0.3 & 8.2 \\
\hline \hline
\end{tabular}

The measurement result is listed in Table I. From the table, it is obtained that the maximum power output is 88.1 Watt, i.e. when the sun irradiation is $820 \mathrm{Watt} / \mathrm{m}^{2}$. It is noted that the measurements of voltage, current, and power are read from the meter of charge controller. Therefore, due to the accuracy of the instrument, the power output is not exactly equally with the multiplication of the voltage and the current shown in the table.

\section{2) Measurement of PV output due to the halogen lamp} lighting

The power output of PV when it is illuminated by the halogen lamp is listed in Table II. From the table, it is obtained that the maximum power output is 11.9 Watt, i.e., when the irradiation is $889 \mathrm{Watt} / \mathrm{m}^{2}$. The comparison of PV output due to the sun lighting and the halogen lamp lighting is given Table
III. In the table, the comparison is performed according to the closest values of irradiation. The results show that for the same (close) value of irradiation, the power output of PV when illuminated by the halogen lamp is lower (about 1/6) of the one by the sun. It could be understood from the fact that the Solar Power Meter used to measure the irradiation measures the irradiation level without considering the spectrum of the light. Since the energy extracted by the PV is affected by the spectrum of the light (sun light), the power generated by PV when illuminated with the halogen lamp is lower than the one with the sun, even the irradiation level is the same.

TABLE II. MEASUREMENT RESUlt USING SOLAR SimULATOR

\begin{tabular}{lllll}
\hline \hline $\begin{array}{l}\text { Height of } \\
\text { halogen } \\
\text { lamp } \\
\text { from PV } \\
\text { (cm) }\end{array}$ & $\begin{array}{l}\text { Irradiation } \\
\left.\text { (Watt/m } \mathbf{m}^{2}\right)\end{array}$ & $\begin{array}{l}\text { Voltage } \\
\text { output } \\
\text { (Volt) }\end{array}$ & $\begin{array}{l}\text { Current } \\
\text { output } \\
\text { (Ampere) }\end{array}$ & $\begin{array}{l}\text { Power } \\
\text { output } \\
\text { (Watt) }\end{array}$ \\
\hline \hline 55 & 889 & 25.6 & 0.5 & 11.9 \\
65 & 659 & 25.6 & 0.5 & 11.7 \\
75 & 516 & 25.5 & 0.4 & 11.1 \\
85 & 385 & 25.5 & 0.4 & 9.2 \\
95 & 365 & 25.5 & 0.4 & 9 \\
105 & 330 & 25.5 & 0.3 & 8 \\
\hline \hline
\end{tabular}

TABLE III. COMPARISON BETWEEN SUN VS SOLAR SIMULATOR

\begin{tabular}{|c|c|c|c|c|c|}
\hline \multicolumn{3}{|c|}{ Solar Simulator } & \multicolumn{3}{|c|}{ Sum } \\
\hline $\begin{array}{l}\text { Height } \\
\text { of } \\
\text { halogen } \\
\text { lamp } \\
\text { from } \\
\text { PV (cm) }\end{array}$ & $\begin{array}{l}\text { Irradi- } \\
\text { ation } \\
(\text { Watt/ } \\
\left.\text { m }^{2}\right)\end{array}$ & $\begin{array}{l}\text { Power } \\
\text { output } \\
\text { (Watt) }\end{array}$ & Time & $\begin{array}{l}\text { Irradi- } \\
\text { ation } \\
(\text { Watt/ } \\
\left.\mathbf{m}^{2}\right)\end{array}$ & $\begin{array}{l}\text { Power } \\
\text { output } \\
\text { (Watt) }\end{array}$ \\
\hline 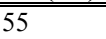 & 889 & 11.9 & $11: 30$ & 820 & 88.1 \\
\hline 65 & 659 & 11.7 & $11: 00$ & 660 & 67.6 \\
\hline 75 & 516 & 11.1 & $10: 00$ & 570 & 61.2 \\
\hline 85 & 385 & 9.2 & $09: 30$ & 456 & 49.1 \\
\hline
\end{tabular}

\section{B. Wind Power Simulator Measurement}

The experiment on wind power simulator is conducted by connecting the output of generator to the charge controller, where its output is connected to the battery. In the experiment, the speed of motor coupled with the generator is varied to simulate the wind's speed. The result is given in Table 4 . While the graph of power output vs the motor speed is shown in Fig. 6 . From the figure, it is obtained that the relationship between the DC motor speed and the power output of generator is almost linear. However, the power output is still small (below than 10 Watt).

TABle IV. MEASUREMENT Result OF Wind POWER Simulator

\begin{tabular}{lllll}
\hline $\begin{array}{l}\text { DC } \\
\text { motor } \\
\text { voltage } \\
\text { input } \\
\text { (Volt) }\end{array}$ & $\begin{array}{l}\text { DC motor } \\
\text { speed } \\
\text { (Rpm) }\end{array}$ & $\begin{array}{l}\text { DC } \\
\text { generator } \\
\text { current } \\
\text { output } \\
\text { (Ampere) }\end{array}$ & $\begin{array}{l}\text { DC } \\
\text { generator } \\
\text { voltage } \\
\text { output } \\
\text { (Volt) }\end{array}$ & $\begin{array}{l}\text { DC } \\
\text { generator } \\
\text { power } \\
\text { output } \\
\text { (Watt) }\end{array}$ \\
\hline \hline 26 & 554.1 & 0.1 & 24.6 & 2.1 \\
27 & 566.5 & 0.1 & 24.6 & 2.6 \\
28 & 580.6 & 0.2 & 25.1 & 4.3 \\
29 & 594.3 & 0.2 & 25.1 & 6.0 \\
30 & 607.3 & 0.3 & 25.2 & 7.4 \\
31 & 620.9 & 0.4 & 25.3 & 9.9 \\
\hline \hline
\end{tabular}




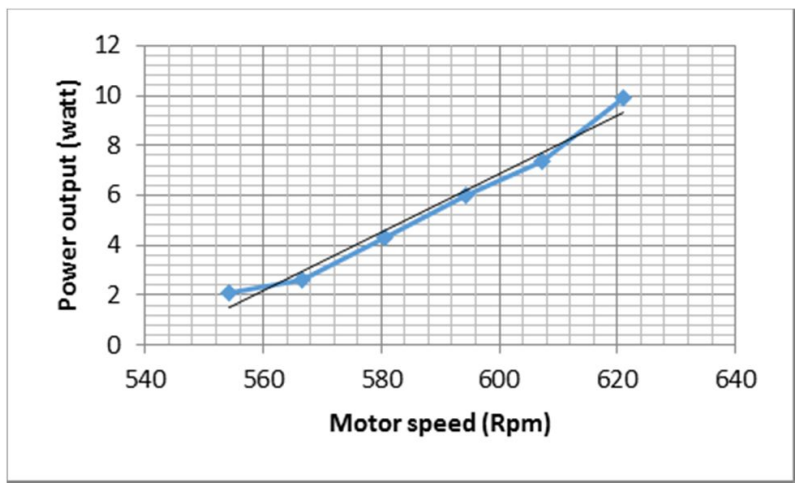

Fig. 6. The graph of power output vs motor speed.

\section{Load Flow Measurement}

The load flow measurement is conducted by connecting the grid tie inverters to the grid and measuring the power on each side (line). The aim of this measurement is to verify that the grid tie inverter works properly by penetrating the power to grid. In the experiments, the load power is varied as shown in Table V. In the table, the appendix (R) means that the grid receives the power.

TABle V. Result of LOAD Flow MEASUREMENT

\begin{tabular}{lllll}
\hline \hline No. & $\begin{array}{l}\text { Load } \\
\text { (Watt) }\end{array}$ & $\begin{array}{l}\text { Power } \\
\text { supplied by } \\
\text { grid (Watt) }\end{array}$ & $\begin{array}{l}\text { Power } \\
\text { supplied by } \\
\text { solar } \\
\text { generator } \\
\text { (Watt) }\end{array}$ & $\begin{array}{l}\text { Power } \\
\text { supplied by } \\
\text { wind } \\
\text { generator } \\
\text { (Watt) }\end{array}$ \\
\hline \hline 1 & No load & $298(\mathrm{R})$ & 124 & 173 \\
2 & 108 & $182(\mathrm{R})$ & 123 & 170 \\
3 & 219 & $80(\mathrm{R})$ & 122 & 170 \\
4 & 338 & 49 & 118 & 170 \\
5 & 442 & 158 & 116 & 167 \\
6 & 549 & 266 & 115 & 165 \\
\hline \hline
\end{tabular}

From Table V, we can observe several cases as follows. In case-2, when the load power is 108 Watt, the power supplied by solar generator and wind generator is 123 Watt and 170 Watt respectively. While the grid receives the power of 182 Watt. The power delivered to the grid is $123+170=293$ Watt. While the power received by the grid and the load is $108+182=290$ Watt. Thus the power of 3 Watt is lost in the system. It may be absorbed by the grid tie inverters.

In case-5, the load power is 442 Watt. In this case, three energy resources (grid, solar power, and wind power) deliver the power to the load. Thus total power delivered is $158+116$ $+167=441$ Watt. There is a power loss of 1 Watt in the system.

The results in Table $\mathrm{V}$ show that the grid tie inverter works properly, in the sense that it is able to synchronize with the grid for delivering the power to the load.

\section{CONCLUSION}

The hardware testbed for implementing the hybrid windsolar power system was developed. The developed solar simulator and the wind simulator could be employed to simulate the varying conditions of those power generator systems. Further, the grid tie inverter used in the work was able to deliver the power from the solar power and the wind power to the grid system.

In future, the system will be expanded by implementing various algorithms in the hybrid power system. The capacity and complexity of hybrid system will be improved.

\section{REFERENCES}

[1] A. Islam, A. Azam, S. W. Protity, S. Chakma and A. Das, "Grid connected hybrid solar system with MPPT charge controller," In Proc. 2016 IEEE International WIE Conference on Electrical and Computer Engineering (WIECON-ECE), Pune, 2016, pp. 122-125.

[2] M. Dali, J. Belhadj, X. Roboam, "Hybrid solar-wind system with battery storage operating in grid-connected and standalone mode: control and energy management-experimental investigation," Energy, vol. 35, no.6, pp. 2587-2595, June 2010.

[3] N. R. Nair and M. Ebenezer, "Operation and control of grid connected wind - PV hybrid system," In Proc. 2014 International Conference on Advances in Green Energy (ICAGE), Thiruvananthapuram, 2014, pp. 197-203.

[4] S. P. L. Rao, C. P. Kurian, B. K. Singh, K. Abhinav and G. Nandy, "Design and simulation of grid connected hybrid solar-WECS using SIMULINK/MATLAB," In Proc. 2014 International Conference on Advances in Energy Conversion Technologies (ICAECT), Manipal, 2014, pp. 241-247.

[5] N.T., Pathan, S.P., Adhau, P.G., Adhau, M.M., Sable, "MPPT for grid connected Hybrid Wind Driven PMSG-Solar PV Power Generation System with Single Stage Converter," Journal of Electrical and Power System Engineering, vol. 3, no. 1, pp. 41-49, 2017.

[6] P. Gupta and S. K. Tripathi, "Analysis of grid-tied hybrid wind PV generation system," in Proc. 2014 Innovative Applications of Computational Intelligence on Power, Energy and Controls with their impact on Humanity (CIPECH), Ghaziabad, 2014, pp. 447-451.

[7] O. A. Soysal and H. S. Soysal, "Case study: Performance of a small gridtie wind-solar generation system," in Proc. 2014 IEEE PES General Meeting | Conference \& Exposition, National Harbor, MD, 2014, pp. 1-5.

[8] A. Al-Durra, A. Reznik, M. G. Simões and S. M. Muyeen, "Performance analysis of a grid-tied inverter for renewable energy applications," In Proc. IECON 2014 - 40th Annual Conference of the IEEE Industrial Electronics Society, Dallas, TX, 2014, pp. 4981-4987.

[9] V. M. Phap, N. Yamamura, M. Ishida, J. Hirai and N. T. Nga, "Design of novel grid-tied solar - Wind hybrid power plant using photovoltaic cell emulating system," in Proc. 2016 IEEE International Conference on Sustainable Energy Technologies (ICSET), Hanoi, 2016, pp. 186-189.

[10] N. Mahmud, A. Zahedi and A. Mahmud, "Dynamic voltage regulation of grid-tied renewable energy system with ANFIS," in Proc. 2016 Australasian Universities Power Engineering Conference (AUPEC), Brisbane, QLD, 2016, pp. 1-6.

[11] S. Z. Hassan, Hui Li, T. Kamal and M. Awais, "Stand-alone/grid-tied wind power system with battery/supercapacitor hybrid energy storage," In Proc. 2015 International Conference on Emerging Technologies (ICET), Peshawar, 2015, pp. 1-6.

[12] T. Abderrahim and B. Said, "Control and management of grid connected PV-Battery hybrid system based on three-level DCI," In Proc. 2017 6th International Conference on Systems and Control (ICSC), Batna, 2017, pp. 439-444.

[13] A. Soetedjo, Y.I. Nakhoda, A. Lomi, T.A. Suryanto, "Solar Simulator Using Halogen Lamp for PV Research," Proceedings of Second International Conference on Electrical Systems, Technology and Information 2015 (ICESTI 2015), Bali, 2015.

[14] http://www.epsolarpv.com/en/index.php/Product/pro_content/id/573/am $\mathrm{id} / 136$

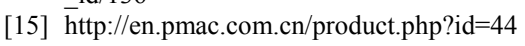

[16] http://www.tenmars.com/webls-en-us/TM-206.html 


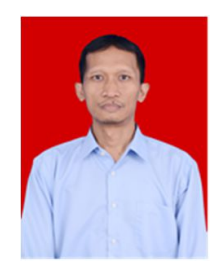

Aryuanto Soetedjo (M'17) received the B.Eng. and M Eng. degree in Electrical Engineering from Bandung Institute of Technology, Indonesia in 1993 and 2002, respectively, and the Dr. Eng. degree in Information Science and Control Engineering from Nagaoka University of Technology, Japan in 2006. He is currently a Senior lecturer and Head of Control laboratory in the Department of Electrical Engineering, National Institute of Technology, Malang, Indonesia. His main research interests are in control system, image processing, machine learning, and robotics.

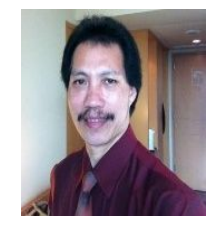

Abraham Lomi (SM'17) received Engineer degree in Electrical Power Engineering from National Institute of Technology, Malang in 1988. His Master of Engineering earned for Department of Electrical Engineering, Bandung Institute of Technology, Indonesia and Doctor of Engineering from Energy Program, Asian Institute of Technology Thailand, in 1992 and 2000, respectively.
Dr. Lomi is a full Professor in Electrical Power Engineering. Currently, he is a Director of Renewable Energy Research Center and Power \& Energy Simulation Laboratory. His research area of interest include power system stability and dynamic, power electronics, power quality, renewable energy, and smart grid technology. Professor Lomi is a member of The Institution of Engineering and Technology (IET), Indonesian Institute of Engineers, International Association of Engineers (UK), IEEE Smart Grid and other professional membership

Mr. Bayu Jaya Puspita was a students in the Department of Electrical Engineering, National Institute of Technology, Malang and major in Control System since 2012. He was also a Laboratory Assistant and did some projects in control system as a research member. He was graduated and earned Bachelor of Engineering in 2016. 